\title{
SEMANTIC CONTENT OF THE TERM CASH FLOW
}

\author{
Vladan Pavlovićl`, Goranka Knežević ${ }^{2}$, Awedat Marai ${ }^{3}$ \\ ${ }^{1}$ University of Pristina, Faculty of Economics, 156 kolasinska Street, Kosovska Mitrovica, Serbia \\ ${ }^{2}$ Singidunum University, 32 Danijelova Street, Belgrade, Serbia \\ ${ }^{3} \mathrm{Al}-$ Gabel El-Gharbi University, Faculty of accounting, Gharian, Libya
}

\begin{abstract}
:
The term Cash flow and its semantic content are frequently used among practitioners and academic accountants without any doubt or knowledge of its semantic content. The authors of course books in the domain of financial accounting use this term without providing its definition, as they consider it clear and familiar. If we take into consideration the fact that this term is widely used in financial analysis, it seems that its content should be clearly stated, or else the results of the analysis may be jeopardized. When we observe the academic literature in the are of financial statement analysis, there is certain confusion regarding the content of this term. By using the content analysis and reading the texts from the financial analysis and accounting textbooks, we have found out that no author is trying to define the term Cash flow, and that they use the term without providing any explanation. This confusion has reached a wider scope after the IASC (now IASB) adopted the IAS 7 Cash flow statement, reporting on various Cash flow segments: Operating cash flow, Investment cash flow and Cash flows from financing activities. As a result of imposing mandatory reporting on the given Cash flow segments, a lot of confusion has been created about the meaning of this term.
\end{abstract}

\section{Key words:}

cash flow,

operating cash flow, cash flow insolvency.

\section{INTRODUCTION}

The term cash flow is widely used in Serbian academic literature in the area of accounting and finance and it is also used in everyday communication among accounting practitioners and business people. The translation of this term into Serbian means "novčani tok“, „tok novca“ or „gotovinski tok". However, most of our authors so not translate this term but use its English version. The term cash flow has been used in all neighboring countries organized as autonomous countries after the decomposition of SFRJ. The usage of English term is not the matter of novelty in Serbia or the matter of intellectual snobbery or insufficient knowledge of mother tongue but the practice of using the original term is the same even in countries where the awareness about the native language and national identity is at a very high level. Thus, the term cash flow is used in France, Germany, Italy, Spain etc. The domestic French term is La capacité d'autofinancement $C A F$, in German language it is Mittelzufluss, in Italian Flusso di cassa, in Spanish Flujo de caja. (see: Annexs - lexique international des termes d'analyse financière in: Vernimmen, et al., 2010). The main issue of using the original English term instead domestic still remain. The answer to this issues can be given only if we take into consideration the semantic content and meaning of this term.

\section{THE PURPOSE OF USING THE FINANCIAL ANALYSIS BASED ON THE CASH FLOW CONCEPT}

Nowadays, it is commonly understood that the concept of cash flow is unavoidable, not only from the perspective of managing liquidity, but also from the perspective of evaluation of the liquidity position of a company, its solvency and earnings power. There is no doubt that the traditional analysis of the ability of a company to pay debts when due (liquidity analysis) is based on balance sheet items and ratios, should be accompanied with the analysis based on the a cash flow ratios. The earnings concept is accrual not based on the cash flow. If we take into consideration that the debts are paid with cash, it means that the solvency analysis should be also based on cash flows. The necessity of using cash flow concept for the solvency analysis should not be elaborated herein because academicians know that insolvency can be caused by over indebtedness or inadequate cash flows to meet all obligations/ debts- short and long term. The term cash flow insolvency is used in some countries in their laws regarding bankruptcy (see also: Pavlović \& Milačić, 2013).

The profitability analysis or earnings power analysis should be accompanied with the cash flow as well. The profitability flows reflect the real earnings power of a company, but the results can be transferred from one accounting period to anoth- 
er one because of inadequate timing of expense and revenue recognition. The results can also be distorted with creative accounting techniques and that is why the results sometimes reflect the false picture of earning power of a company. The methods for detection of creative accounting and the methods for quantifying the effects of manipulation can be seen in the work of Marai and Pavlovic (2014).

The authors from the area of financial and managerial accounting and business finance find that the book readers have clarified the semantic content of the term cash flow, so they do not exhaust themselves in explaining the cash flow calculation in these textbooks. There are few authors who use the term operating cash flow in the analysis. Business people are confused when they are faced with the problem of the semantic content of a cash flow.

\section{WHAT DOES THE TERM CASH FLOW REALLY MEAN?}

Cash flow concept of analysis emerged in the 50-ties in the United States (Ranković 1999:163). Under the influence of American business practice, the usage of the term Cash flow has been widely accepted in Europe. However, based on its rapid and non-critical, huge confusion about the cash flow content was evident (Ranković,1999:163). It was interesting back then, that in Serbian academic literature, professor Ranković in 1975 wrote that this term „was part of many academic debates in the last decade in the American and European literature...where different interpretations of the content of cash flow and its usage cause confusion and ambiguity and stimulate even more debates" (Ranković, 1975). In domestic and foreign literature this confusion has not been solved yet, but to make things even worse, it seems that confusion has even been bigger now.

The different interpretations of the term, in the initial period, were the consequence of using cash flow by practitioners and different financial analysis have different goals and support various caculations and content of cash flows. For various purposes of the analysis, the analysts use different cash flows (see more in: Ranković, 1999: 164-165). It does not matter whether the cash flow is used in the financial and earnings power analysis, from the the very first period of using this concept, it was known that what matters was the cash flow from operations. Undoubtedly, the term cash flow does not consist of inflows from loans and bonds and shares issued and the outlfows that are the result of satisfying loan obligations and owners withdrawals. It is also out of the question that the outflows regarding the fixed assets purchases are not part of the term cash flow. „The capacity of internal financing" (La capacité d'autofinancement - CAF), the French term for the cash flow, does not cause any confusion about its content. If the cash flow reflects the capacity of internal financing than it seems that operating activities and their cash flows only matter. All other cash flows are not relevant for evaluating this capacity.

However, the vast majority of practitioners and non-academic public does not consider the above mentioned semantic content under the term cash flow. Peterson and Fabozzi (2006:174) state that there is a big confusion about the content of the term. Some belive that the term cash flow means the total amount of cash inflows in the company during the specific period of time, while other believe that it means the total amount of inflows earned in the operating section during the period of time. The third parties believe that the term cash flow is used as total cash outflows from the company, the fourth group of authors belive that it means the outflows from operating section only, while the fifth means that cash flow is the difference between total inflows and outflows of money during some period of time. The question arises as to what is the source of such confusion....

\section{THIS IS WHERE THE CONFUSION LIES...}

Peterson and Fabbozi (2006:174) state that there is no concrete definition of a cash flow, which could be the main source of confusion.

As there is no widely accepted definition of a cash flow, this term or sintagma can be used for all previously mentioned purposes. However, some authors have attempted to define the term cash flow. Thus, Thomsett (1998) in the dictionary stated that the term cash flow means increases and decreases in the working capital affected by fluctuating revenues or expenses. In the respectable dictionary of Le Robert \& Collins Business: Dictionnaire Francais-Anglais Anglais-Francais / French-English / English-French Dictionary (2006: 596), cash flow was defined as net profit plus amortization and potential obligations (reserves) using the term net margin of self-financing (Marge brute d'autofinancement MBA). The above-mentioned definitions of a cash flow do not come as a surprise. The main confusion was raised when the set of financial statements was broaden. The introduction of the Statement of financial position, which has been mandatory in the American practice since 1971 (AICPA, American Institute of Certified Public Accountants) has widened this confusion. "The explanatory power of this Statement was found limited, so the analysis of the sources and usage of funds was added. Many companies back then prepared this Funds flow statement using the net working capital concept - calculating the sources of working capital and its usage over time. After that, many companies prepared this report using the cash flow concept, which was prepared as a detailed version of cash flows from operating, investing and financing activities (Peterson \& Fabozzi, 2006: 176). This form of reporting was suggested by the Financial Executives Institute и Financial Accounting Standards Board - FASB, which in 1987 published FAS 95 - Statement of Cash flows, as a replacement for the Accounting Principles Board - APB 19. Introduction of this standard FAS 95 in the American business practice has been accompanied by many controversies and was enacted owning to the one prevailing vote (McEnroe, 1995. According: Ibidem).

After the year 1992, the confusion was broader because IAS 7 was published and this IASC (International Accounting Standards Committee) standard forced companies to prepare and report Funds Flow report based on the cash flow basis and it was named Cash flow statement. Singh (2007: 135) found that Cash flow Statement was very good term for the Funds flow Statement based on the cash flow concept. By renaming this report into the Cash flow statement, it was obvious that cash flow means operating cash. However, this report and its investing and financing sector have increased confusion, becasue many authors have started to think that the term cash flow expanded to financing and investing cash flow. 


\section{CONCLUSION}

The term Cash flow has no unique and theoretically sound semantic content because it is mainly driven by the goals of the cash flow analysis. The main arising from the use of this term was the consequences of different cash flows and non clarified usage of this term as an instrument of financial analysis. The term cash flow in academic literature is used in the context of cash flow from operations which is an integral part of the Statement of Cash Flows. Bearing in mind that the confusion is evident, the business practice shows that some authors use a more clarified term cash flow from operations instead of using cash flow. Nevertheless, the accounting standards interpret the cash flow from operations differently, which leads to not having the precise definition of its content.

There is no doubt that the term cash flow does not include the inflows and outflows from financing and investing section, but only the inflows and outflows from operations. Taking into consideration the non- precise definitions of the term cash flow, the conclusion can be derived that it is more convenient to use its English term without trying to translate it, as that could worsen the situation and cause greater confusion.

\section{REFERENCES}

Duval, A., \& Smith, S. (2006). Le Robert \& Collins Business: Dictionnaire Francais-Anglais Anglais-Francais / French-English / English-French Dictionary. Paris: Dictionnaires Le Robert.

Marai, A., \& Pavlović, V. (2014). An overview of earnings management measurement approaches: Development and evaluation. Facta universitatis: Economics and Organization, 11(1), 21-36.

Peterson, P., \& Fabozzi, F. (2006). Analysis of Financial Statements. Hoboken, NJ: John Wiley \& Sons.

Pavlović, V., \& Milačić S. (2013). Neujednačen semantički sadržaj termina solventnost - izvorište i posledice. Zbornik Matice srpske za društvene nauke, br.144, str. 451-466.

Ranković, J. (1975). Upravljanje finansijama radnih organizacija. Beograd: Zavod za savremenu organizaciju poslovanja

Ranković, J. (1999). Upravljanje finansijama, deveto ponovljeno izdanje. Beograd: Ekonomski fakultet.

Singh,Y.P. (2007). Accounting and Financial Management for I.T. Professionals. New Delhi: New Age International.

Thomsett, M. (1998). Mastering Fundamental Analysis. Chicago: Dearborn Finanical.

Vernimmen, P., Quiry, P., \& Le Fur, Y. (2010). Finance d'entreprise, 8e édition par Pascal Quiry \& Yann Le Fur. Paris: Dalloz.

\section{SEMANTIČKI SADRŽAJ TERMINA CASH FLOW}

\section{Apstrakt:}

Stručna i akademska javnost često se služi engleskim terminom Cash flow bez svesti o različitom semantičkom sadržaju koji se ovom terminu pridaje. Autori stručne literature iz oblasti finansijskog računovodstva po pravilu koriste ovaj termin bez prethodnog definisanja, podrazumejvajući da je njegovo značenje jasno i nedvosmisleno. Činjenica da se engleski termin Cash flow često koristi u finansijskoj analizi, uprkos različitom semantičkom sadržaju koji mu se pridaje, dovodi do dvosmislenog tumačenja rezultata analize. Iako je do zabune u vezi sa značenjem ovog termina dolazilo i pre, ona će poprimiti veće razmere nakon usvajanja računovodstvenog standarda MRS 7- Izveštaj o tokovima gotovine od strane Komiteta za međunarodne računovodstvene standarde (sadašnji Odbor za međunarodne računovodstvene standarde), prema kome se izveštava o različitim segmentima novčanih tokova, i to: novčanim tokovima iz poslovnih aktivnosti, novčanim tokovima iz aktivnosti investiranja i novčanim tokovima iz aktivnosti finansiranja. Propisivanje obaveze izveštavanja o pomenutim segmentima termina Cash Flow dovelo je do opšte zabune oko njegovog pravog značenja.

\section{Ključne reči:}

Cash flows (novčani tokovi) novčani tokovi iz poslovnih aktivnosti, insolventnost novčanih tokova. 